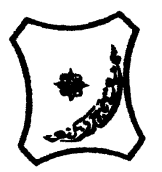

Received: March, 2015

Accepted: May, 2015

ISSN $2006-6996$

\title{
PREVALENCE OF BITING AND NON-BITING FLIES IN RELATION TO SPECIES IN THE JOS MUSEUM ZOOLOGICAL GARDEN, NORTH CENTRAL NIGERIA
}

${ }^{1} *$ Njila, H.L, ${ }^{1}$ David, S. and ${ }^{2}$ Ombugadu, A.

1. Department of Science Laboratory Technology, University of Jos, P.M.B. 2084, Jos, Nigeria

2. A. P. Leventis Ornithological Research Institute, Department of Zoology, University of Jos,

P.M.B. 2084, Jos, Nigeria

*Correspondence author:njilahl@yahoo.com

\begin{abstract}
Several Dipteran flies are vectors of diseases in the Afro-tropical region. The study was carried out to determine the species abundance of biting and non biting flies prevalent at the Jos Museum Zoological Garden, north central Nigeria. The flies were trapped using Biconical traps during the raining season of August -September 2013. The flies were harvested three times a week at an interval of 48 hours. Stomoxys calcitrans is the most abundant species trapped. There were significantly more flies in the Lion, Bovidae (Donkey, Carmel and Horse) and Ostrich sites compared to Human routes, Chimpanzee and Hyena sites suggesting a correlation between flies abundance and body size of animal. Flies proportions were compared using Chi-square test. There is a significant difference in the abundance of biting and non-biting flies. There is also a significant difference in the abundance of flies in relation to species and trapping sites. The biting effects on resident animals and tourists were discussed. The Jos Museum Zoological Garden being the oldest and second largest tourist destination in Nigeria will require concerted efforts to put in proper control measures to prevent flies infestation. This can be done through improved hygienic conditions and wastes management.
\end{abstract}

Key words; Biting, flies, Garden, Museum, Zoological

\section{INTRODUCTION}

The most interesting part of insect-man relationship and insect-animal relationship is the aspect of disease transmission (Dye, 1992 and Sachs and Malaney, 2002). The sufferings that man goes through in the prevention, curative and treatment of these diseases on himself, his domestic animals or livestock and his crops gives the overwhelming impression that the insects have no overall useful purpose on earth (Jessup, 1985; Allan et al., 1987 and David,1994). There are four ways in which insects appear to be dangerous to man and animals. These include annoying effects, injection of venoms by bites and stings, parasitic feeding on man or animal and finally transmission of diseases to man and animals (Balashov, 1984; David, 1994 and Blackwell and Page 2003). Many researchers, students and tourists from all over the world visit the Jos Museum Zoological Garden to carry out their studies or for recreational purposes. Unconfirmed reports from previous visits to the Zoological Garden have shown that biting and non-biting flies exists. It has been reported that vector diversity, abundance and distribution could influence transmission risk to host animals because vectors select their preferred hosts from pool of available susceptible hosts (Okoth et al., 2007 and Udoidung et al., 2007).

The aim of this study therefore is to investigate the species abundance of biting and nonbiting flies in the Jos Museum Zoological Garden in Nigeria.

\section{MATERIALS AND METHODS}

Study Area

Jos is a city in the north central Nigeria bounded on the north and west by the Kaduna plains (an average of 600 meters) and on the south by the Benue plains (about 300 meters). Geographically, Jos Plateau lies between latitudes $8^{\circ} 30^{\prime}$ and $10^{\circ} 30^{\prime}$ North and Longitudes $7^{\circ} 30^{\prime}$ and $8^{\circ} 37^{\prime}$ East, with a population of about 3,206,531 residents based on the 2006 census. The land surface of the Jos Plateau consists of plains, hills and depressions (Ajakpo and Okonkwo, 1984).

The climate of Jos Plateau is a function of interaction of two main factors. These are its high altitude and position which reflects the path of seasonal migration of Inter Tropical Convergence Zone (ITCZ). The high altitude of Jos Plateau has so much moderated temperature, which has been described as temperate-like while its position in relation to Inter Tropical Convergence Zone determines the sequence of seasons. The approximate maximum high temperature is about $22^{\circ} \mathrm{C}$ while the mean minimum low temperature is about $18^{\circ} \mathrm{C}$ (Ajakpo and Okonkwo, 1984). The Jos Museum Zoological Garden was opened to the public in 1952. It is located in the heart of the city and found on Longitude $9^{\circ} 54^{\prime} 51^{\prime \prime}$ North and Latitude $8^{\circ}$ 53' 9"East. The Jos Museum Zoological Garden consists of museum and the Zoo. 
Bajopas Volume 8 Number 1June, 2015

The museum is the oldest museum in Nigeria after the small museum at Esie near Ilorin, which was opened in 1945. It is the second largest museum in the country offering a wide range of exhibits and facilities for visitors. The Garden is often quite but noisy during the weekends and attracts large number of tourists. All these have necessitated the choice of the Garden for this research.

\section{Trapping Techniques}

A total of Ten Biconical traps produced from royal blue and black cotton fabric and white synthetic mosquito netting were mounted within various animal cages and near human (tourists) routes. The selection of animal trapping sites was as follows: Chimpanzees, Lion Ostrich, Hyena and Bovidae (Carmel, Donkey and Horse). Five Traps were mounted on cleared vegetation in the animal cages and five traps were mounted between $50-100 \mathrm{~m}$ apart along the human routes. Flies were trapped during the raining season of August -September 2013. The flies were harvested three (3) times a week at an interval of 48 hours. In each traps all flies caught were immobilized with ethyl acetate solution $(0.001 \%)$ and transferred into sampling bottles containing $70 \%$ alcohol, $10 \%$ glycerine and $20 \%$ distilled water and taken to the laboratory where they were sorted out to species levels and counted Sutherland, (1996). Identification was according to keys provided by Pont (1973) and Castner (2000).

\section{Statistical Analysis}

Data obtained were analyzed using $\mathrm{R}$ Console software (Version 2.9.2). Flies proportions were compared using Chi-square test. Statistical significance was achieved if $P<0.05$.

\section{RESULTS AND DISCUSSION}

An overall total of 3,032 flies were trapped at the end of this study. The high abundance of flies trapped is an indication of an improper waste management and lack of hygiene in the Jos Museum Zoological Garden which was attributed to heaps of refuse close to cages and within cages of animals investigated in this study. In addition animal dung's removed from the cages are dumped inside or outside the cages (Pers. Obs.). This has made the cages and animals susceptible to infestation. This is in conformity with the works of Du Toit et al. (2004) and Hammond (1992) who revealed that, animal cages and environment when left unattended encourage the growth of micro-organisms and increase greatly insect's abundance. Donald and Evans (2006) also showed that dirt and debris hide pests and prevent them from being detected until serious damage has occurred. Khalil et al. (1994) and Boadi and Kuitunen, (2005 ) reported that in third world countries hygienic conditions of Zoological Gardens are often poor, leading to increase disease transmission by insects as well as increase in breeding sites by accumulation of debris and deficient drainage systems.

There is a significant difference $\left(\square^{2}=\right.$ 92.4444, df $=1, P<0.001$ ) in the abundance of biting in relation to species (Table 1 ). Whereas 1,144 individuals representing $61.11 \%$ were Stomoxys calcitrans, 729 individuals representing $38.89 \%$ were Haematopota pluvialis (Table 1). However, there is no significant difference $\left(\square^{2}=1.2448\right.$, df $=1, P=$ 0.2645 ) in the abundance of non-biting flies in relation to species (Table 2). The breakdown of the result revealed that 599 (51.64\%) were Musca domestica while 561 (48.36\%) were Fannia canicularis (Table 2).

The observed significant and non-significant differences in the abundance of biting and non-biting flies (Tables 1 and 2) is consistent with the findings of Daniel and Kingsolver (1983), Balashov, (1984), Burkot, (1988) and McCall and Kelly, (2002) who opined that flies abundance is associated to host preference, feeding habits and habitats. Martin et al. (1994) showed that biting insects are widely distributed in forested areas and represent a potentially important disturbance to animals living in cages. This agrees with our findings that the gallery forest within the Jos Museum Zoological Garden support high abundance of biting flies due to the favourable conditions within the forest for breeding, refuge and easy migration of adult females to animal cages to seek for blood meal.

Table 1: Abundance of Biting Flies in Relation to Species in the Jos Museum Zoological Garden

\begin{tabular}{lccc}
\hline Site & Stomoxys calcitrans & $\begin{array}{c}\text { Haematopota } \\
\text { pluvialis }\end{array}$ & Total(\%) \\
\hline Chimpanzee & 47 & 75 & $122(6.52)$ \\
Lion & 439 & 317 & $756(40.38)$ \\
Ostrich & 223 & 155 & $378(20.19)$ \\
Hyena & 113 & 50 & $163(8.71)$ \\
*Bovidae & 255 & 120 & $375(20.03)$ \\
Human routes & 67 & 11 & $78(4.12)$ \\
\hline Total & $\mathbf{1 1 4 4}$ & $\mathbf{7 2 8}$ & $\mathbf{1 8 7 2}$ \\
\hline Percent (\%) & $\mathbf{6 1 . 1 1}$ & $\mathbf{3 8 . 8 9}$ & $\mathbf{1 0 0}$ \\
\hline
\end{tabular}

*(Donkey, Horse and Camel)

$\square^{2}=92.4444$, df $=1, \mathrm{P}<0.001$ 
Bajopas Volume 8 Number 1June, 2015

Table 2: Abundance of Non-biting Flies in Relation to Species in the Jos MuseumZoological Garden

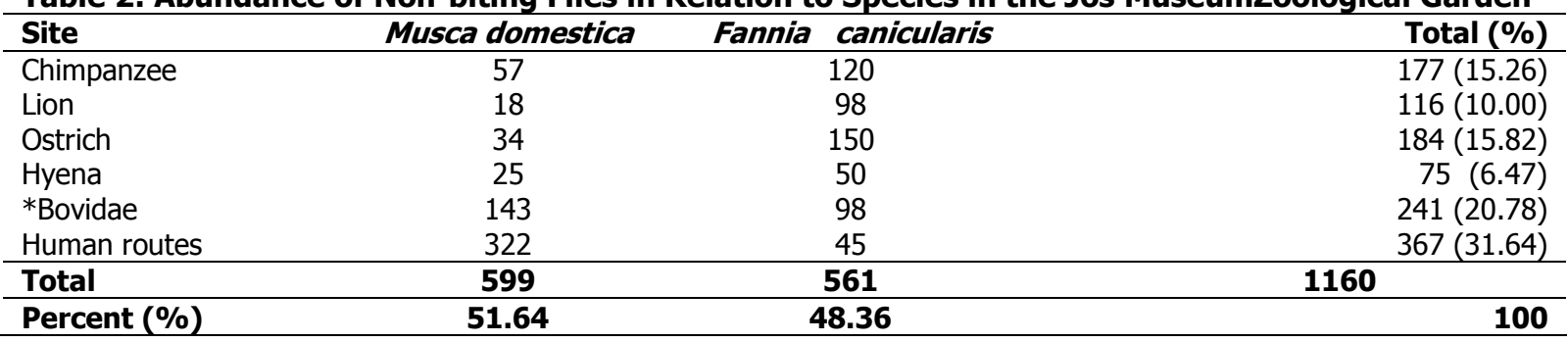

* (Donkey, Horse and Camel)

${ }^{2}=1.2448, \mathrm{df}=1, \mathrm{P}=0.2645$

High abundance of $S$. calcitrans and $H$. pluvialis in this study might be due to their thirst for blood meal which is evident to injuries caused to animals by these species as was observed on their ears and other body parts on which the flies congregated upon. The head region particularly the ear was surrounded by clouds of small flies, which were found to be among the four species caught. It was also discovered that this phenomenon is associated with rainy season in most animal homes or ranch as revealed by Steve and Peter (1996). This study reveals that animals were observed trying to chase away clouds of flies with much resistance from the flies.

This study clearly showed that infestation of animal's by $S$. calcitrans, $H$. pluvialis, M. domestica and $F$. canicularis in the Jos Museum Zoological Garden results in blisters and erosion of ears which serves as entrance point for disease transmission and eventually leads to death of animals. However, due to degree of infestation, the animal's body especially the ears become deformed and unattractive to tourists thereby diminishing the touristic attraction of Jos Museum Zoological Garden. The constant interruption of feeding and grazing by activities of flies can cause malnutrition thereby making the animals look emaciated. Often times, visitors to the Zoological Garden are disturbed by biting flies especially those visitors that visit with sleeveless clothes or shorts, thereby causing psychological and emotional stress to them. This agrees with the report of Blackwell and Page (2003) that M. domestica are important pest of livestock and humans which cause considerable discomfort and disrupt normal grazing or outside activities of animals and people alike. The low abundance of $M$. domestica and $F$. canicularis might be due to their lack of thirst for blood meal, but are considered mechanical vectors, disseminating diseases such as typhoid fever, cholera, salmonellosis, bacillary dysentery, tuberculosis, anthrax, helminths and

many other pathogens of importance to public health (Sulaiman et al., 2000; Graczyk et al., 2001 and Rahuma et al., 2005).

There were significant differences $(P=0.001)$ in the abundance of flies in relation to species and sampling sites (Table 3). A detailed analysis of this result showed that there were $1,144 \quad(37.73 \%)$ individuals of Stomoxys calcitrans (Diptera: Muscidae)and 561 (18.50\%) individuals of Fannia canicularis (Diptera: Muscidae). S. calcitrans and $F$. canicularis are the most abundant and least abundant species of flies trapped in the Jos Museum Zoological Garden respectively (Table 3). Conversely, there were more flies in the Lion (28.76\%), Bovidae (20.32\%) and Ostrich $(18.54 \%)$ sites compared to Human routes $(14.68 \%)$, Chimpanzee $(9.86 \%)$ and Hyena $(7.85 \%)$ sites respectively (Table 3 ).

The observed significant difference in the abundance of flies in relation to sampling sites (Table 3) is also consistent with the reports of Burkot, 1988; Kelly, 2001; McCall and Kelly, 2002 who attributed this trend to flies choice to feed on particular individuals from among preferred species, which may well have implications for disease transmission.

In this study, Lion and Bovidae were identified as major host suggesting a correlation between flies abundance and animal body size. Daniel and Kingsolver (1983) affirmed that biting flies congregate more for blood meals on animals that possess large and exposed body parts. This trend was very visible with Lion and Bovidae's ears. Their ears could be seen to be eroding gradually due to continuous perching and biting activities of flies. Similarly, the chimpanzees spend most of the time scratching their bodies which results in the furs being broken down thus exposing their bodies to flies

Table 3: Abundance of Biting and Non-biting Flies in Relation to Sampling Sites in the Jos Museum Zoological Garden

\begin{tabular}{|c|c|c|c|c|c|c|c|c|}
\hline & \multicolumn{8}{|c|}{ Sampling Sites } \\
\hline & Species & $\begin{array}{c}\text { Chimpanze } \\
\text { e }\end{array}$ & Lion & $\begin{array}{c}\text { Ostric } \\
h\end{array}$ & Hyena & $\begin{array}{c}\text { Bovidae } \\
*\end{array}$ & $\begin{array}{c}\text { Huma } \\
\text { n } \\
\text { routes }\end{array}$ & Total (\%) \\
\hline \multirow[t]{2}{*}{ Biting Flies } & SC & 47 & 439 & 223 & 113 & 255 & 67 & $1144(37.73)$ \\
\hline & $H p$ & 75 & 317 & 155 & 50 & 120 & 11 & $728(24.01)$ \\
\hline Non-Biting & $M d$ & 57 & 18 & 34 & 25 & 143 & 322 & $599(19.76)$ \\
\hline \multirow[t]{3}{*}{ Flies } & $F C$ & 120 & 98 & 150 & 50 & 98 & 45 & $561(18.50)$ \\
\hline & Total & 299 & 872 & 562 & 238 & 616 & 445 & 3032 \\
\hline & Percent (\%) & 9.86 & 28.76 & 18.54 & 7.85 & 20.32 & 14.68 & 100 \\
\hline
\end{tabular}


Bajopas Volume 8 Number 1June, 2015

\section{CONCLUSION}

This study has established some biting and nonbiting flies prevalent at the Jos Museum Zoological Garden. It is therefore a challenge to the management of Jos Museum Zoological Garden to

\section{REFERENCES}

Ajakpo, J.E. and Okonkwo, L.O. (1984):The Jos Plateau and the adjoining lowlands, A fieldGuide, $4^{\text {th }}$ Edition, Department of Geography and Planning, University of Jos.66pp.

Allan, S. A., Day, J. F. and Edman, J. D. (1987): Visual ecology of biting flies. AnnualReview of Entomology,32: 297-316.

Balashov, Y. (1984): Interaction between bloodsucking arthropods and their hosts, and its influence on vector potential. Annual Review of Entomology, 29: 137 -56.

Blackwell, A. and Page, S. (2003): Managing tourist health and Safety in the newmillennium: Global perspectives. In Managing Tourist Health and Safety in the New Millennium. Pergamon, 2: 177-96.

Boadi, K.O and Kuitunen, M. (2005): Environmental and health impacts of household solidwaste handling and disposal practices in third world cities: the case of the Accra Metropolitan Area, Ghana. Journal of Environmental Health, 68:32-36.

Burkot, T. R. (1988): Non-random host selection by Anopheline mosquitoes. ParasitologyToday, 4: $156-62$.

Castner, J.L. (2000): Photographic Atlas of Entomology and Guide to insectidentification, Feline Press Gainesville U.S.A. Inc. Pp.74-223.

Daniel, T. L. and Kingsolver, J. G. (1983): Feeding strategy and the mechanics of bloodsucking in insects. Journal of Theoretical Biology,105: 661-72.

David P. (1994): Insect pests in Museums. Archetype Publication Limited London, Pp. 32-51.

Donald, P.F. and Evans, A.D. (2006): Habitat connectivity and matrix restoration: the widerimplications of agric -environment scheme. Journal of Applied Ecology, 43: 209-218.

Du Toit, J.T., Walker, B.H. and Campbell, B.M (2004): Conserving tropical nature: currentchallenges for ecologists. Trends in Ecology and Evolution, 19(1): 12-17.

Dye, C. (1992): The analysis of parasite transmission by bloodsucking insects. AnnualReview of Entomology, 37: 1-19.

Graczyk T.K., Knight R., Gilman R.H. and Cranfield M.R. (2001): The role of non-biting flies in the epidemiology of human infectious diseases. Microbes Infections, 3:231-235.

Jessup W. (1985): Integrated pest management: A program for Museum, Smithsonianinstitution. New York.78p develop workable strategies to meet up with current trends in flies' control. The long term benefits of flies' prevention which can be achieved through improved hygienic conditions and wastes management cannot be over emphasized.

Kelly, D.W. (2001): Why are some people bitten more than others? Trends in Parasitology,17: 578-81.

Khalil, K., Lindblom, G.B., Mazhar, K. and Kaijser, B. (1994): Flies and water as reservoirsforbacterial enteropathogens in urban and rural areas in and around Lahore,Pakistan. Epidemiology of Infections, 113:435-444.

Martin, F.R., McCreadie, J.W., and Colbo, M.H. (1994): Effect of trap site, time of day, andmeteorological factors on abundance of host-seeking mammalophilic black flies (Diptera,Simuliidae). Canadian Entomology,126: 283-289.

McCall, P. J. and Kelly, D.W. (2002): Learning and memory in disease vectors. Trendsin Parasitology, 18: 429-33.

Okoth, S.O., Kokwaro, E.D., Kiragu, J.M. and Murilla, G.A. (2007): Diurnal activity ofallopatric populations of Glossina pallidipes and hosts and their implicationOn risk of transmission of sleeping sickness in Kenya. Journal of Entomology 4:20-32.

Pont. (1973): Insects and other Arthropds of Medical Importance. Edited by Kenneth ,G.V.Smith. The trustees of (The British Museum Natural History) London. Pp.181-225.

Rahuma, N., Ghenghesh, K.S., Ben, A.R. and Elamaari, A. (2005): Carriage by the housefly(Musca domestica) of multipleantibiotic-resistant bacteria that are potentiallypathogenic to humans, in hospital and other urban environments in Misurata,Libya. Annal of Tropical Medical Parasitology, 99:795-802.

Sachs, J. and Malaney P. (2002): The economic and social burden of malaria. Nature 15: 680 685.

Steve M., and Peter H. (1996): Feeding habits of Stomoxys spp. Stable flies in a Kenyanforest. Journal of Medical and Veterinary Entomology, 10: 392-294.

Sulaiman, S., Othman, M.Z. and Aziz, A.H. (2000): Isolations of enteric pathogens fromsynanthropic flies trapped in downtown Kuala Lumpur. Journal of Vector Ecology, 25: 90-93.

Sutherland, W.J. (1996). Ecological Census Techniques. Cambridge University Press. pp 139-177.

Udoidung, N.I.G., Braide, I.E., Opara, K.N. and Adie, H.A. (2007): Perstans fillariasis inrural communities of the lower Cross River Basin Nigeria. Parasitologicalobservations. International Journal of Zoology Research, 3: 207-212. 